\begin{tabular}{l|c|c|}
\hline & International Journal of Current Research in \\
Biosciences and Plant Biology \\
\hline EXCELLENT \\
PUBLISHERS
\end{tabular}

Original Research Article

doi: $\underline{\text { https://doi.org/10.20546/ijcrbp.2018.507.004 }}$

\title{
Distribution and Ecobiological Research of Vetch (Vicia L.) Species in Azerbaijan
}

\author{
K. V. Asadova* and A. M. Asgarov \\ Genetic Resources İnstitute of ANAS, Azadlig Ave. 155, Baku, AZ1106, Azerbaijan \\ ${ }^{*}$ Corresponding author.
}

\begin{tabular}{|c|c|}
\hline Article Info & ABSTRACT \\
\hline $\begin{array}{l}\text { Date of Acceptance: } \\
\text { 22 June } 2018\end{array}$ & \multirow{4}{*}{$\begin{array}{l}\text { In this article was presented the results of seed samples and about } 200 \text { herbarium } \\
\text { specimens of } 17 \text { vetch species collected on } 36 \text { routes from different regions of } \\
\text { Azerbaijan in } 2015-2017 \text {, distribution based on their descriptive data, evaluation } \\
\text { based on morphological and ecological indicators. In the study, first main cluster is } \\
\text { divided to } 12 \text { groups: V. tenuifolia subsp. variabilis (Z02, Z7, E8), which belongs to } \\
\text { subgenus Cracca (according to Radghi, Fedchenko); V. narbonensis (K20)- which } \\
\text { belongs to section Faba, V. villosa (Z3), V. sativa subsp. sativa (Q2, K14, A1-1) - to } \\
\text { section Vicia, V. lutea (C4, K18), V. pannonica (Z4) - to section Hypechusa and V. } \\
\text { abbreviata (Z11)- to section Atossa (according to Kupicha) and the fourth main } \\
\text { cluster which is related to } 10 \text { samples. }\end{array}$} \\
\hline $\begin{array}{l}\text { Date of Publication: } \\
\text { 06 July } 2018\end{array}$ & \\
\hline Keywords & \\
\hline $\begin{array}{l}\text { Cluster analysis } \\
\text { DIVA-GIS } \\
\text { Ecological indicators } \\
\text { Vetch species }\end{array}$ & \\
\hline
\end{tabular}

\section{Introduction}

Vetch (Vicia L.) is one of the most widely spread genera of the Fabaceae Lindl. of the class Magnoliopsida. The species included into the genus are spread across the northern hemisphere, including the middle mountain ranges in Azerbaijan. The species of genus are precious fodder plants. It contains many proteins. Dry and green mass is best used by animals (Brainard, et al. 2012). Vicia was first described by K. Linney (Linneaus, 1753). In the world flora, there are 200 species of vetch (Vicia L.) (Tsvelyov, 1987) and 41-43 species of vetch in Azerbaijan (Asgarov, 2011).
Although different classical botanists in the Caucasus expressed interesting ideas about the genus Vicia L., its classification, and the types in Azerbaijan, B. Fedchenko gave the first comprehensive system of this genus "in the USSR Flora". He divided this genus into 3 subgenera, 4 sections, 31 rows. Forty one species of vetch of Azerbaijan are grouped into 3 subgenera, 20 rows (Fedchenko, 1948).

Although Grossheim described the genus of the "Caucasian flora" (1952), he adopted the system of Fedchenko. He noted that that there are 150 species 
of vetch in the world, 48 wild species and one cultivar in Caucasus (Grossheim, 1952). In 1970, Dagestani botanist A. D. Radghi published the Caucasian species of Vicia L. genus. In own proposed system, Radghi adopted a large number of subsections and series (Seriaes) within the sections, using the division of the genus into the sub-genera. She has shown the spread in total 36 species of this genus and has grouped them into 3 subgenera, 8 section, 19 subsection and 12 series (Radghi, 1971). 28 wild and 1 cultivated species of Azerbaijan were divided into 3 subgenera, 8 sections, 16 subsection and 11 series in this system.

In the 80's, the Petersburq botanic Tsvelyov developed the system of Vicia genus spreading in eastern Europe. Here, too, the division of genera into subgenera is accepted. The Caucasus, including Azerbaijan, is also reflected in this system. He has divided the Vicia genus into 3 subgenera (Cracca, Ervum and Vicia) and sections (Oroboidea, Cracca, Lenticula, Ervum, Ervilia, Sepium, Hypechusa, Vicia, Lathyroides, Pseudolathyrus and Faba), has given series of Radji within the subseries and has described several new sections (Oroboidea, Lenticula, Ervilia, Hypechusa, Lathyroides and Pseudolathyrus). In 1987, Tsvelyov improved the system of Vicia, which he proposed earlier in the "Flora of the European part of USSR" (Tsvelyov, 1987).

Systematic of the Vicia L. genus of Turkish flora were studied by P. Davis and U. Plitman (Davis, Plitmann, 1970). In this system vetch species has been distributed in 3 groups. Turkish species has been grouped into 58 wild and 1 cultural species in 3 groups, Azerbaijanian species has been grouped into 26 wild and 1 cultural species in 3 groups.

The only taxonomic study on the whole genus was conducted by F. K. Kupicha at the world level (Kupicha, 1973, 1975, 1976). Kupicha (1979) referred to this genus of Vicieae tribe in "The taxonomic studies in the tribe Vicieae (Leguminosae)" and gave information about 11 sections of genus. Although in the multivolume "Flora of Azerbaijan" have been described 41 wild species, 1 cultivar, in "The plant world of
Azerbaijan" of A. Asgarov it has been given the information on 43 wild species of and 1 cultivar (Asgarov, 2016), the varietal systematics of genus and the biomorphological diversity have not been widely studied.

Vetch (Vicia L.) is one of the highest quality, two and perennial fodder grass. Morphological signs are important in systematic of vetch species, as well as in the design of the prescribed keys. The main characteristic of the genus is the too the column, correlation of crown and calyx lobe, and the leaf finish with clasper. The calyx tube is usually curved from the base. The vexillum is hollow or full. The wing petals are joined to slipcover. The column is thoroughly hirsute or unilateral bearded on the top, rarely naked. Species are distinguished by the color of the crown, the shape of the flower, the characteristics of the leaf and stipule, the fruit sand seeds.

The leaves are pair featherlike, ends with many or less branched beads, or with a sharp end, sometimes with a single leaf. Stipules are often semi-gothic shaped. The flowers are 1 or 2-3, locate in the axillary bud, almost as a sessile or cluster is multi flowered. The peduncle is longer than the leaves, or equal to it, and sometimes is shorter. The corolla is yellow, red, purple, blue, blue, matte or dark purple, red-purple, blue, yellowish-orange, bright purple, pale blue, bright blue and so on in colors. Calyx is 5 toothed, usually it has 3 upper are longer than 2 down teeth. The corolla resembles is a common butterfly structure. 9 adjacent stamens form a pipe, and 1stamen is free. The vexillum is undescribed claw, the wings are almost equal to the claw, slipcover is blunt, shorter than the vexillum, sometimes with the same length. The stem is gentle or sloppy, externally tight or sparse, sometimes almost naked, flat shield or creeping. Legume is on short or long stalk; Legume is too or less squeezed; it is hirsute or sliced; cylindrical, bead shaped. Usually it is multi-seeded, and sometimes it is twoseeded. Legume is soft, fluffy, or bare. Cytological studies show that the genus has a chromosome set of $2 \mathrm{n}=10,12,14,16,18,28$ (Davis and Plitmann, 1970; Kupicha, 1973; Tsvelyov, 1987). 


\section{Materials and methods}

In 2015-2017, in the Department of Ecobotanics and Systematics of the Institute of Genetic Resources, under the guidance of A. Asgarov at the expeditions on 36 routes from different regions of Azerbaijan 17 species (about 200 herbarium specimens) and seeds were collected and studied. Moreover, collections of the Herbarium Funds of the Institute of Botany of ANAS, the Genetic Resources Institute (AGRI) and the Institute of Botany of the Republic of Georgia (TBI) were studied as a research material. The literature and Internet data have been analyzed. The definition of the nomenclature issues is based on The International Botanical Code (Austria, Vienna, 2005; Allkin et al., 1986) In the determination of species and identification of their nomenclature were used "Flora of Azerbaijan" and A. Asgarov's books (Asgarov, 2011 and 2016), in the analysis of other features were used Ch. Raunkier (Raunkiaer,
1937) and I. Serebryakov's classification (Serebryakov, 1964). Comparative morphological (Gunn and Kluve, 1969, 1970 and 1976) floristic (Tupikova, 1926), biomorphological, sistematic (Maxted, 1990 and 1995) phytocenological and experimental methods (Leht, 2005) were used in the research. Range maps of the collected species were compiled using DIVA-GIS computer program. The amount of annual rainfall, temperature information is based on the PAST program.

\section{Results and discussion}

The distribution of the vetch species is based on five major botanical-geographical regions of Azerbaijan: 1. Greater Caucasus, 2. Lesser Caucasus, 3. Kura-Araks, 4. Talysh region and 5. Nakhchivan. Distribution of Vicia L. species in botanical-geographical regions of Azerbaijan is given in Table 1.

Table 1. Distribution of Vicia L. species in botanical-geographical regions.

\begin{tabular}{|c|c|c|c|c|c|c|}
\hline \multirow[b]{2}{*}{ No. } & \multirow[b]{2}{*}{ Name of species } & \multicolumn{5}{|c|}{ Botanical-geographical regions } \\
\hline & & $\begin{array}{l}\text { Greater } \\
\text { Caucasus }\end{array}$ & $\begin{array}{l}\text { Lesser } \\
\text { Cauasus }\end{array}$ & $\begin{array}{l}\text { Kura- } \\
\text { Araks }\end{array}$ & Talysh & Nakhchivan \\
\hline 1 & $\begin{array}{l}\text { Vicia abbreviata Fisch. ex Spreng. } \\
\text { (V.truncatula Fisch. ex Bieb.) }\end{array}$ & + & + & + & + & + \\
\hline 2 & V. alpestris Stev. & + & & & & \\
\hline 3 & V.amphicarpa Lam. & + & + & & + & \\
\hline 4 & V. anatolica Turrill (V.hajastana Grossh.) & & & & & + \\
\hline 5 & $V$. angustifolia Reichard & + & + & + & + & + \\
\hline 6 & V. antiqua Grossh. & + & + & & & \\
\hline 7 & V. balansae Boiss. & + & + & & & + \\
\hline 8 & V. bithynica (L.) L. & + & & & + & \\
\hline 9 & V. boissieri Freyn & + & + & & + & \\
\hline 10 & $\begin{array}{l}\text { V. cappadocica Boiss.et Bal. } \\
\text { (V. paucijuga (Trautv.) B. Fedtsch.) }\end{array}$ & & & & + & + \\
\hline 11 & V.cassubica $\mathrm{L}$ & + & & & + & \\
\hline 12 & V.caucasica Ekvtim. & + & & & & \\
\hline 13 & $\begin{array}{l}\circ \text { V. ciceroidea Boiss. } \\
\text { (V. rafigae Tamamsch.) }\end{array}$ & & & & & + \\
\hline 14 & V.cilliatula Lipsky & + & & & + & \\
\hline 15 & V. cordata Wulf. ex Hoppe & + & & + & + & + \\
\hline 16 & V. crocea (Desf.) Fritsch & + & + & & + & \\
\hline 17 & V. elegans Guss. & & + & & & + \\
\hline
\end{tabular}




\begin{tabular}{|c|c|c|c|c|c|c|}
\hline \multirow[b]{2}{*}{ No. } & \multirow[b]{2}{*}{ Name of species } & \multicolumn{5}{|c|}{ Botanical-geographical regions } \\
\hline & & $\begin{array}{l}\text { Greater } \\
\text { Caucasus }\end{array}$ & $\begin{array}{l}\text { Lesser } \\
\text { Cauasus }\end{array}$ & $\begin{array}{l}\text { Kura- } \\
\text { Araks }\end{array}$ & Talysh & Nakhchivan \\
\hline 18 & V. ervilia (L.) Willd. & + & + & & + & + \\
\hline 19 & V. grandiflora Scop. & + & + & + & + & + \\
\hline 20 & V. grossheimii Ekvtim. & + & + & & & + \\
\hline 21 & $\circ$ V. hololasia Woronow & + & + & & & \\
\hline 22 & V.hirsuta (L.) S.F.Gray & + & + & & + & + \\
\hline 23 & V. hybrida $\mathrm{L}$. & + & + & + & + & + \\
\hline 24 & V. hyrcanica Fisch. et C.A.Mey. & & & & + & + \\
\hline 25 & V. iberica Grossh. & + & & & & \\
\hline 26 & V. larissae Prima & + & & & & \\
\hline 27 & V. lathyroides L. & & + & & + & \\
\hline 28 & $\begin{array}{l}\circ V . \text { loiseleurii (Bieb.) Litv. } \\
\text { (V. meyeri Boiss.) }\end{array}$ & + & & & + & \\
\hline 29 & V. lutea $\mathrm{L}$ & + & & & + & + \\
\hline 30 & $\begin{array}{l}\text { Vicia monantha ssp. monantha Retz. } \\
\text { (V. cinerea Bieb.) }\end{array}$ & + & + & + & + & + \\
\hline 31 & $\begin{array}{l}V . \text { narbonensis L. } \\
\text { (V. johannis Tamamsch.) }\end{array}$ & + & + & + & + & + \\
\hline 32 & V. nissoliana L. (V.variegata Willd.) & & + & & & + \\
\hline 33 & V. pannonica Crantz & + & + & + & + & + \\
\hline 34 & V. peregrina $\mathrm{L}$. & + & + & + & + & + \\
\hline 35 & V. pilosa Bieb. & & + & & & \\
\hline 36 & V. sativa $\mathrm{L}$ & + & + & + & + & + \\
\hline 37 & V. semiglabra Rupr.ex Boiss & + & & & & \\
\hline 38 & V. serratifolia Jacq. & & & & + & \\
\hline 39 & V.sepium L. & + & + & & & \\
\hline 40 & V. tetrasperma (L.) Schreb. & + & + & & + & + \\
\hline 41 & V. variabilis Freyn et Sint. & + & + & + & + & + \\
\hline 42 & V.varia Host (V. dasicarpa Auct.) & + & + & + & + & + \\
\hline 43 & V. villosa Roth. & + & & & & \\
\hline \multicolumn{2}{|c|}{ Total } & 34 & 26 & 12 & 27 & 24 \\
\hline
\end{tabular}

The results of our research show that the vetch is more widely spread in the Greater Caucasus region of Azerbaijan (34 species). From the species of vetch 27 spread in Talysh region, 26 in the Lesser Caucasus, 24 in Nakhchivan, and 12 species in Kura-Araks. 36 routes were selected in different regions of Azerbaijan for exploration of vetch species, distinguished by certain bioecological characteristics, and were coded for identification. Range maps of the collected species were compiled using DIVA-GIS computer program (Fig. 1). The ecological and geographical data, including the name of species, collection areas with locality code, data about latitude and longitude, sea level, vegetation period, ecological groups, of the collected species from the research area are presented in Table 2.

As can be seen from Table 2, the most types were collected from meadows (13 species), at least types from planting area (2 species). Ecological assessment of vetch species on climate parameters has been carried out. It was found that in the min height was observed in $V$. cordata $(-20 \mathrm{~m})$ from Apsheron region, Goradil settlement, and $V$. bithynica $(-25 \mathrm{~m})$ in Masally region, Tekle village territory, Max height from Lerik region, Mistan village were collected $V$. peregrina $(1723 \mathrm{~m})$, and $V$. elegans, $V$. nissoliana from Ordubad region, Paragha village (1644 m). 


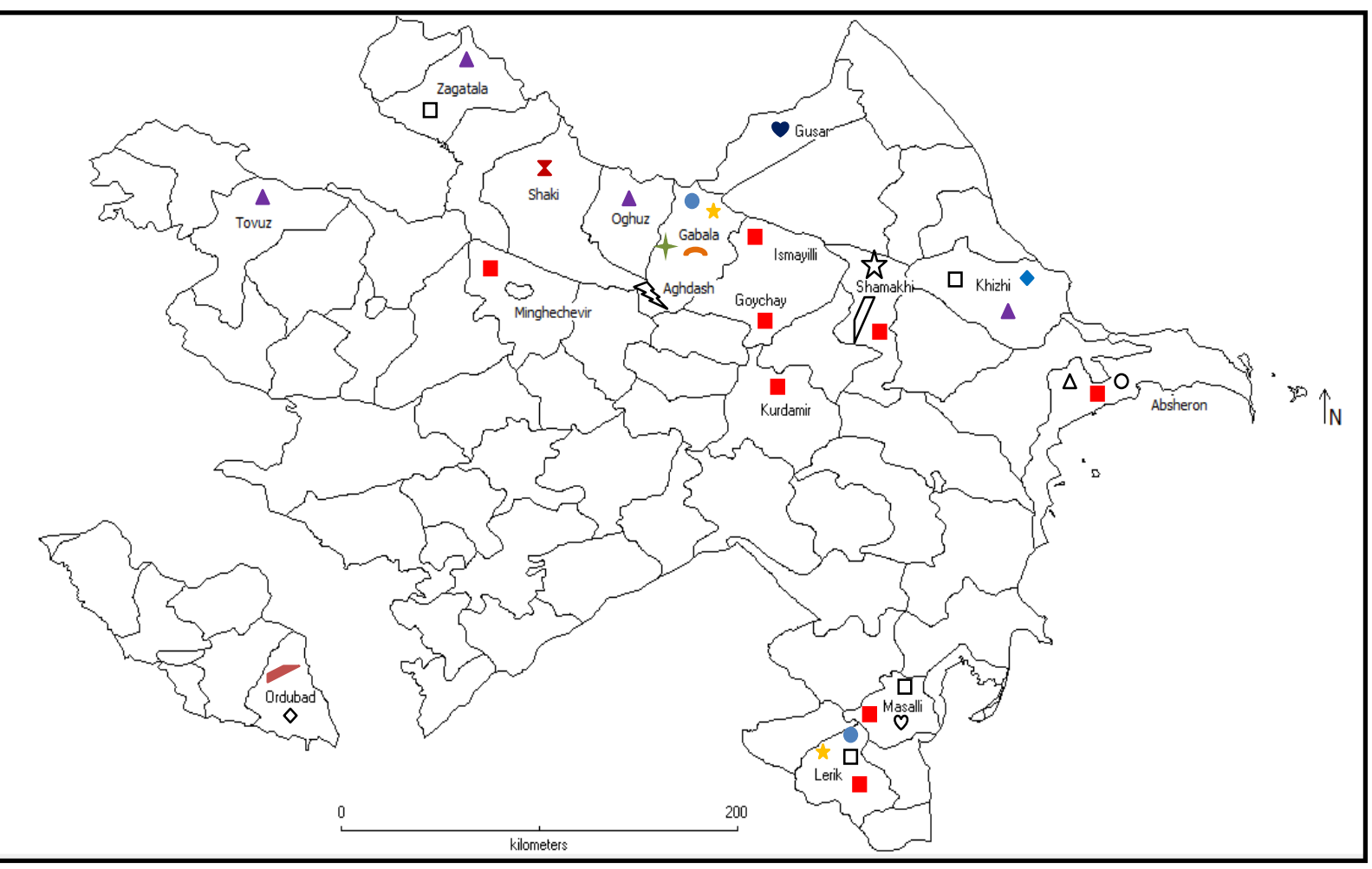

Fig. 1: -V. peregrina; - V. sativa subsp. nigra; $\square-V$. tetrasperma; $\Delta-V$. tenuifolia subsp. variabilis; $\triangle$ - V. cordata; $\diamond-V$. elegans; $\diamond$ - V. grandiflora; $V$-V. lutea; - V. nissoliana; - V.

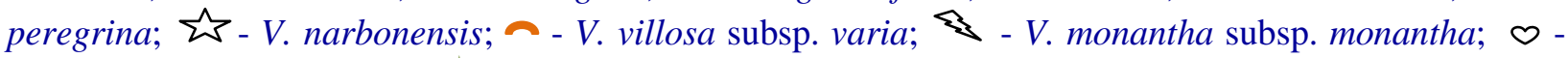
V. bithynica; - V. hirsuta; † - V. pannonica; $\mathbf{X}$-V. abbreviata.

Table 2. Ecological and geographical information on Vicia L. species collected from the investigation area.

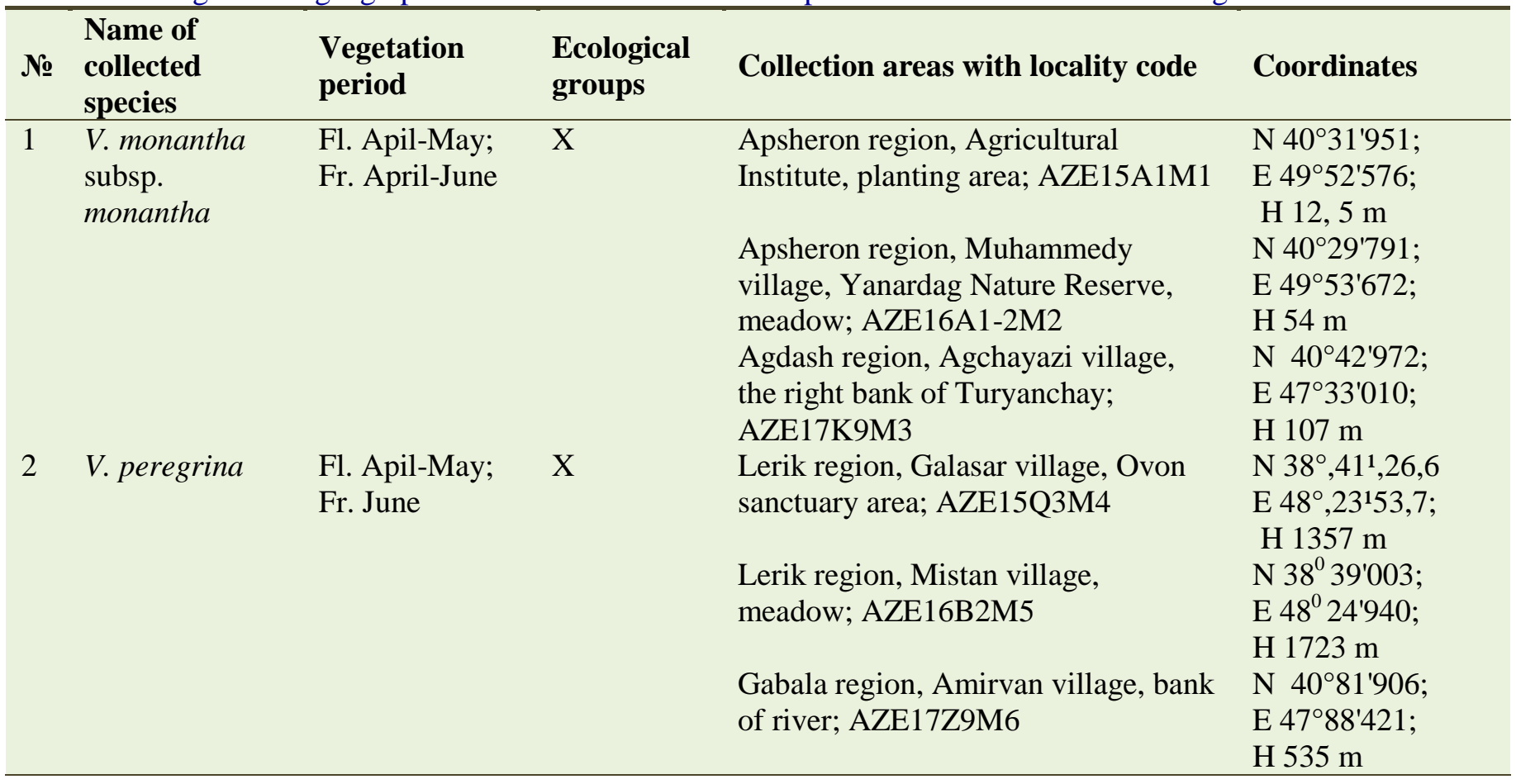




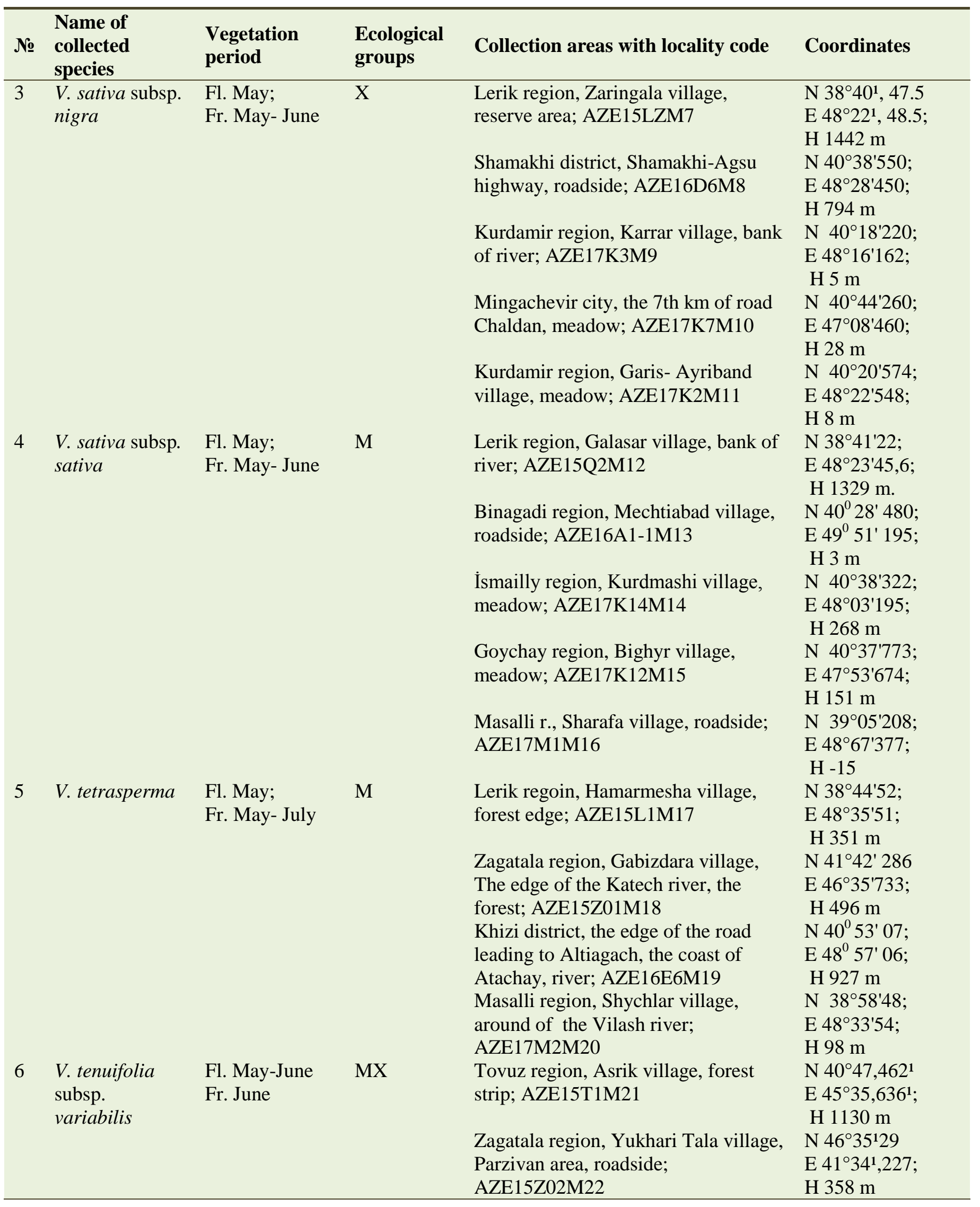




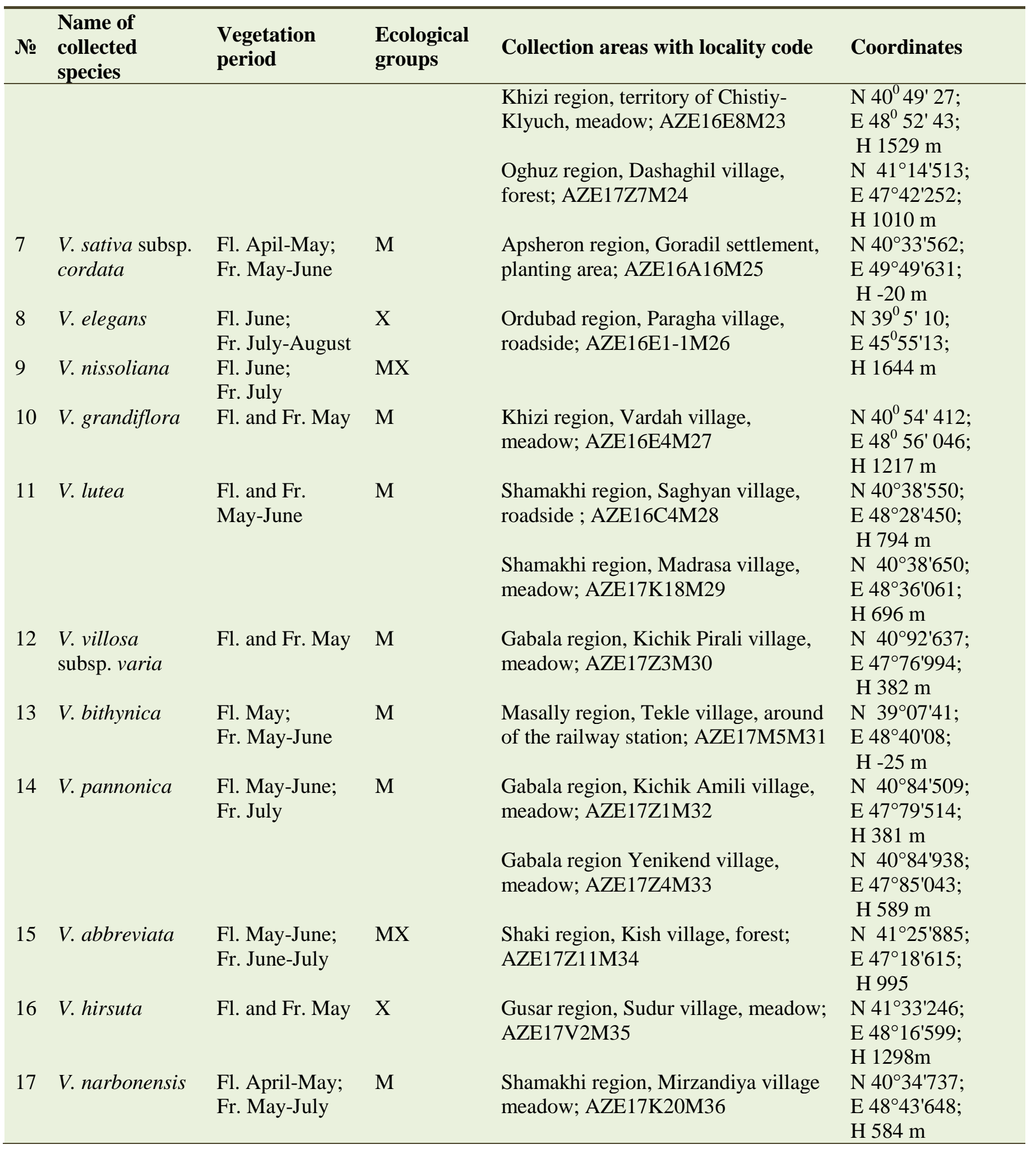

Due to environmental factors in the biomorphological structure of species have been observed significant changes. Information about the amount of annual rainfall, temperature $\left(\mathrm{T}_{\min }\right.$ minimum temperature, $\mathrm{T}_{\max }-$ maximum temperature for month and $\mathrm{T}_{\mathrm{oi}}$ - average annual temperature) is established by using program DIVA-GIS and is as follow (Fig. 2). The average annual rainfall has 
been determined by the fact that on $\min$ rainfall was collected for $V$. peregrina, V. sativa subsp. nigra, $V$. tetrasperma from territory of Kurdamir region, Karrar village $(360 \mathrm{~mm})$, on the maximum rainfall $V$. lutea and $V$. narbonensis were collected from territory of Masally region, Kalinovka village (701 $\mathrm{mm})$. Min temperature for January was encountered in territory of Oguz region, Dashagil village ($17.4^{\circ} \mathrm{C}$ ), max temperature in territory of Geokchay region, Bighyr village, $\left(33.2^{\circ} \mathrm{C}\right)$. Min average annual temperature was observed in territory of Oguz region, Dashagil village $\left(-7.5^{\circ} \mathrm{C}\right)$, max average annual temperature in territory of Mingachevir city, the 7 th $\mathrm{km}$ of road Chaldan $\left(20.5^{\circ} \mathrm{C}\right)$.

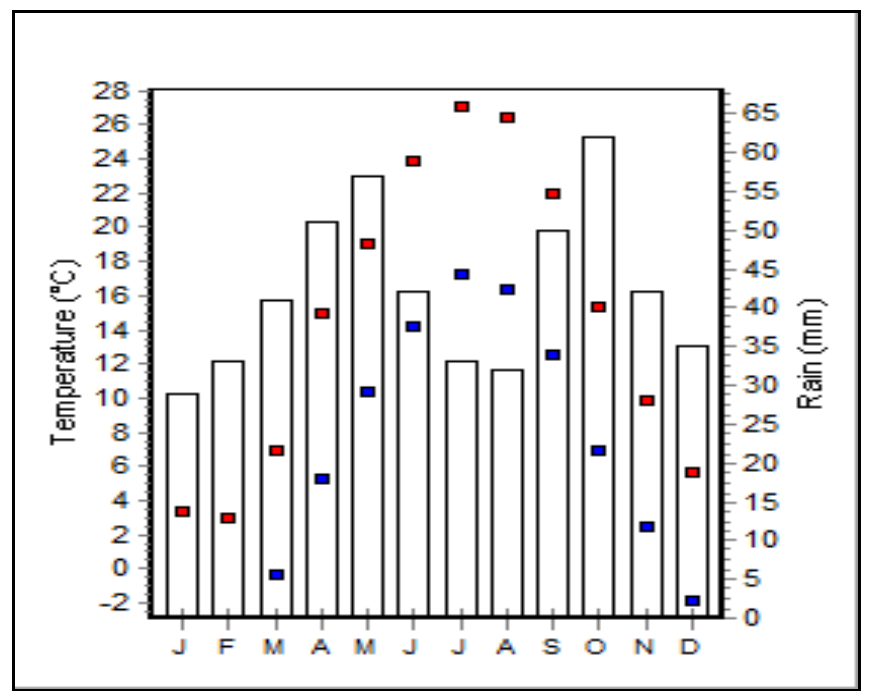

Fig. 2: Average annual rainfall and temperature of collected samples. $\square$ - The red square is the maximum temperature indicator $\left(\mathrm{T}_{\max }\right)$; - The blue square is the minimum temperature indicator $\left(\mathrm{T}_{\text {min }}\right) ; \square$ - Monthly precipitation $(\mathrm{mm})$;

In 2015-2017, 17 species were selected for phenethical (taximetric) analysis of vetch species during the 36 expedition researches. At least two samples were studied from each population and each population was marked as Operational Taxonomic Unit (OTU). For the biomorphological analysis, 33 quantitative and qualitative characteristics were selected. At least 2-3 sample parameters taken from each population were measured and the average score was calculated.
Based on the results, by using the Cluster Analysis method was carried out a taximetric analysis. The analyzes were conducted through the SPSS Win (SPSS 16.0) program. The phenomenon (taximetric) relationship between Vicia L. species is shown in Fig. 3.

As can be seen from the Table, 4 main clusters were observed at the 12 level. The first main cluster is divided to 12 groups: $V$. tenuifolia subsp. variabilis (Z02, Z7, E8), which belongs to subgenus Cracca (according to Radghi, Fedchenko); V. narbonensis (K20)- which belongs to section Faba, V. villosa (Z3), V. sativa subsp. sativa (Q2, K14, A1-1) - to section Vicia, V. lutea (C4, K18), V. pannonica (Z4) - to section Hypechusa and V. abbreviata (Z11)- to section Atossa (according to Kupicha).

The second cluster is related to 4 samples: $V$. monantha subsp. monantha (A1, A1-2, K9), $V$. nissoliana (E1-2), which belongs to section Cracca (according to Radghi, Kupicha). The third main cluster is composed of 4 samples: $V$. tetrasperma (L1, M2, E6), which belongs to section Ervum, $V$. elegans (E1-1) - to section Cracca (according to Radghi, Kupicha).

Finally, the fourth main cluster is related to 10 samples: V. peregrina (Q3, B2, Z9), which belongs to section Peregrinae, V. sativa subsp. nigra (LZ, D6, K2) - to section Vicia, V. bithynica (M5) - to section Faba (Kupicha). V. sativa subsp. cordata (A16), V. grandiflora (E4), which belongs to section Vicia and V. hirsuta (V2) - to section Cracca (according to Kupicha). The species studied belong to morphological and ecological groups. Some samples of the first cluster are mesophytes and annual plants- $V$. narbonensis (K20); V. villosa (Z3); V. sativa subsp. sativa (Q2, K14, A1-1); V. lutea $(\mathrm{C} 4, \mathrm{~K} 18), V$. pannonica $(\mathrm{Z} 4)$, and others are mesoxerophytes and perennial plants- $V$. abbreviata (Z11), V. tenuifolia subsp. variabilis (Z02, Z7, E8) (Serebryakov, 1964). Some samples of the second cluster are xerophytes and annual plants- $V$. monantha subsp. monantha (A1, A1-2, K9), but other is mesoxerophyte and perennial plant- $V$. nissoliana (E1-2). 
In the third cluster 3 samples are mesophytes and annual plants- $V$. tetrasperma (L1, M2, E6), and other sample is xerophyte and perennial plant $-V$. elegans (E1-1). Finally, in the fourth cluster 7 samples are xerophytes and annual plants- $V$. peregrina (Q3, B2, Z9), V. sativa subsp. nigra (LZ, D6, K2), V. hirsuta (V2); but 3 others are mesophytes and annual plants- V. bithynica (M5), $V$. sativa subsp. cordata (A16) and $V$. grandiflora (E4). At the same time, the hipsometric analysis of these species showed that, this species were found in middle and high mountain ranges (Prilipko, 1954). Ground color: brown, sandy clay; water regime: free, without drainage; the side of the slope: south; relief: foothills; oat level: light.

In our research four main clusters are differentiated from each other for having characters: the height of the plant, the number of leaflets, the number of legumes, the number of seeds and their ecological groups.

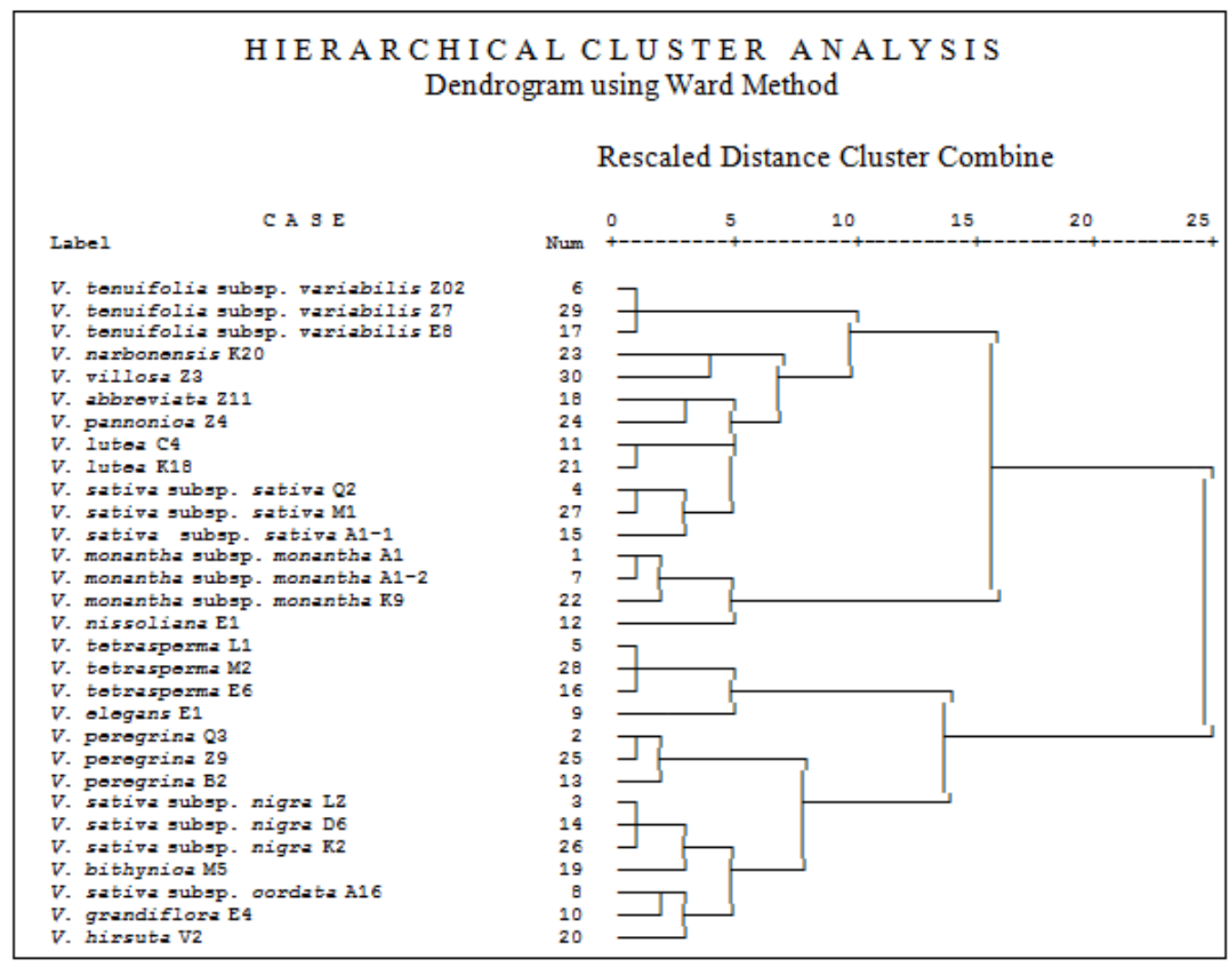

Fig. 3: Unified cluster analysis of morphological characteristics in Vicia L. species.

\section{Conflict of interest statement}

Authors declare that they have no conflict of interest.

\section{References}

Allkin, R., Goyder, D.J., Bisby, F.A., White, R.J., 1986. Names and synonymus of species and subspecies in the Viciae. Issue 3 Vicieae Database Project Publication No. 7,
Southampton.

Asgarov, A. M., 2011. Concept of Azerbaijan's Flora. Baku, Elm. p.204.

Asgarov, A. M., 2016. The plant world of Azerbaijan. Baku, TEAS PRESS. p.444.

Basaran, U., Mut, H., Onal Asci, O., Ayan, I., Acar, Z., 2012. Germination pattern of naturally grown Lathyrus and Vicia species to different methods and seedbeds. Int. J. Plant Prod. 6(3), 325-336.

Brainard, D., Henshaw, B., Snapp, S., 2012. Hairy 
vetch (Vicia villosa Roth.) varieties and bicultures influence cover crop services in striptilled sweet corn. Agron. J. 104, 629-638.

Büyükkartal, H. N., Çölgeçen, H., Pinar, N. M., Erdoğan, N., 2013. Seed coat ultrastructure of hard-seeded and soft-seeded varieties of Vicia sativa. Turk. J. Bot. 37, 270-275.

Davis, P.H., Plitmann, U., 1970. Vicia L. Flora of Turkey and the East Aegean Islands, Edinburgh University Press, Edinburgh. Vol. 3. pp.274325.

Flora of Azerbaijan, 1954. The genus Lathyrus L. Baku: AN Azerbaijan SSR, Vol. V. pp. 513-533

Flora of USSR, 1948. Fabaceae, Vol. XIII. p.406.

Grossheim, A.A., 1952. Species Vicia L. Flora of the Caucasus. M.- L., T.V. pp.400-412.

Gunn, C. R., 1969. Genera, types, and lectotypes in the tribe Vicieae (Leguminosae). Taxon. 18, 725-733.

Gunn, C. R., 1970. A key and diagrams for the seeds of one hundred species of Vicia (Leguminosae). Proc. Int. Seed Testing Assoc. 35, 773-790.

Gunn, C. R., Kluve, J., 1976. Androecium and pistil characters for tribe Vicieae (Fabaceae). Taxon. Vol. 25(5/6), 563-575.

ILDIS, 2010. International Legume Database and Information Service. http:// www.ildis.org/

Kupicha, F. K., 1973. Studies in the Vicieae L.: The new genus Anatropostylia. Notes Royal Bot. Garden. (Edinburgh). 32, 247-250.

Kupicha, F. K., 1975. Observations on the vascular anatomy of the tribe Vicieae (Leguminosae). Bot. J. Linnean Soc. 70, 231-242.
Kupicha, F. K., 1976. The infrageneric structure of Vicia. Notes Royal Bot. Garden (Edinburgh). 34, 287-326.

Leht, M., 2005. Cladistic and phenetic analysis of relationships in Vicia subgenus Cracca (Fabaceae) bazed on morphological data. Taxon. 54(4), 1023-1032.

Linneaus, C., 1753. Species Plantarum Exbientes Plantas Rite Cognitas ad Genera Relatas cum Diferentiis Specificis, Nominibus Trivialibus, Synonymis Selectis, Locis Natalibus, Secundum Systema Sexuale Digestas, Berlin.

Maxted, N., 1990. A revision of Vicia subgenus Vicia using DB technology. Ph.D. thesis, Southampton.

Maxted, N., 1995. An Ecogeographical Study of Vicia subgenus Vicia. Systematic and Ecogeographic Studies on Crop Genepools. International Plant Genetic Resources Institute, Rome, Italy. 190p.

Radghi, А. Д., 1971. Concept of Systems Caucasis Species of Genus Vicia L., News of Systematics Higher Plants. Sankt-Petersburg. Vol. VII. pp.228-240.

Raunkiaer, Ch., 1937. Plant Life Forms. Clarendon Press, Oxford. 104p.

Serebryakov, I. G., 1964. Life forms of higher plants and their study. In the book: Field Geobotany, No. 3. M.; L.

Tsvelyov, N. N., 1987. Europy part of USSR, Vol. VI. p.12.

Tupikova, A. I., 1926. Botanico-agronomical investigation of annual vetches. Bull. Appl. Bot. Plant Breed. 16(i), 151-246.

\section{How to cite this article:}

Asadova, K. V., Asgarov, A. M., 2018. Distribution and ecobiological research of vetch (Vicia L.) species in Azerbaijan. Int. J. Curr. Res. Biosci. Plant Biol. 5(7), 27-36.

doi: https://doi.org/10.20546/ijcrbp.2018.507.004 